\title{
MINIMALLY INVASIVE APPROACH IN ESTHETIC DENTISTRY: COMPOSITE RESIN VERSUS CERAMICS VENEERS
}

\author{
ABORDAGEM MINIMAMENTE INVASIVA EM ODONTOLOGIA ESTÉTICA: \\ RESINA COMPOSTA VERSUS FACETAS CERÂMICAS
}

\author{
Giselle Rodrigues REIS ${ }^{1}$; Ana Laura Rezende VILELA ${ }^{2}$; Fernanda Pereira SILVA ${ }^{1}$; \\ Marcela Gonçalves BORGES ${ }^{2}$; Paulo César SANTOS-FILHO ${ }^{3}$; Murilo de Sousa MENEZES ${ }^{3}$ \\ 1. Adjunct Professor, Department of Dentistry, Dental School, University of Rio Verde, Rio Verde, Goiás, Brazil; \\ 2. Department of Restorative Dentistry and Dental Materials, School of Dentistry, University Federal de Uberlândia - UFU, Uberlândia, \\ MG, Brazil; 3. Adjunct Professor, Department of Restorative Dentistry and Dental Materials, Dental School, Federal University of \\ Uberlândia, Minas Gerais, Brazil. murilosmenezes@yahoo.com.br
}

\begin{abstract}
Unsatisfactory anatomical shape of anterior tooth promotes disharmony in the smile esthetics. The conservative dental esthetic reestablishment treatments has been improved and evaluated with the development of adhesive materials. The adhesive dentistry allowed minimally invasive preparation through direct treatments with composite resin and indirect ceramic laminates veneers. These two treatments methods present advantages and disadvantages. The aim of this manuscript is to describe two clinical reports and compare alternatives to rehabilitate the smile esthetic appearance by direct and indirect minimally invasive treatments. In the first case, a 24-years-old patient, female, complained of unsatisfactory anterior maxillary size and incisal wear. After the functional and esthetic planning, nanoparticle composite resin by free hand technique was indicated to rehabilitation. In the second case, a 24-years-old patient, male, reported dissatisfied with his anterior central incisive shape. On clinical examination, maxillary anterior conoid teeth were verified. Based on this evaluation, a conservative treatment using minimally invasive ceramic veneers in maxillary central and lateral incisor and ceramic fragments on canine was planed to the smile rehabilitation. It can be concluded that conservative treatment using direct composite resin restorations and minimum thickness ceramic veneers laminate, even with their specific limitations and advantages, provide satisfactory esthetic and functional treatment results, preserving the dental structure.
\end{abstract}

KEYWORDS: Tooth preparation. Diastemata. Cosmetic dentistry.

\section{INTRODUCTION}

Unsatisfactory anatomical shape of anterior tooth promotes disharmony in the smile esthetics. Esthetic procedures on sound teeth are usually possible by composite resin and ceramic restorations. The development and improvement of these materials allowed enable perform anterior restorations through minimally invasive procedures (MAGNE; HOLZ, 1996; OQUENDO; BREA; DAVID, 2011; PONTONS-MELO; FURUSE; MONDELLI, 2011; RADZ, 2011; LAYTON; CLARKE, 2013). The appropriate technique and material for each patient are also dependent by time, physical, psychological and economic limitations (KORKUT; YANIKOGLU; TAGTEKIN, 2016).

The introduction of adhesive technology and the continuous improvement of the composite resin proprieties, allowed insert add composite resin material to the surface of tooth and reshape it without prior preparation (DEMARCO et al., 2015, LAYTON; CLARKE, 2013). This type of restoration presents some advantages such as easier repair, lower cost and short clinical time (DONG et al., 1999). However, in some cases, staining, wear and fracture can also be observed (FERRACANE, 2011).

Ceramics are widely used in dentistry due to its capacity to mimic the optical characteristics of enamel, color stability and wear resistance (GRESNIGT; KALK; OZCAN, 2012). Thus, ceramic laminates veneers (CLVs) are mainly used (ALBANESI et al., 2016) to optimize shape, position of tooth, correct diastemata and improve the teeth discoloration (DOZIC et al., 2010). Indirect minimally invasive procedures are used to maximize the esthetics results while a conservative dental structure prepare is performed. It is possible to use a ceramic thickness of $0.3 \mathrm{~mm}$ to $0.7 \mathrm{~mm}$, without mechanic properties disadvantages (GRESNIGT; KALK; OZCAN, 2012). The aim of this manuscript is to describe and compare two anterior rehabilitation alternatives, by direct nanofilled composite resin restorations and ceramic laminates veneers.

\section{Cases Report}

Case 1. Direct composite resin restorations: 
A 24-year-old patient, female, attended to the Dental School of Federal University of Uberlandia, unsatisfied with her smile. She presented the maxillary anterior teeth with unsatisfactory anatomy shape and incisal wear (Figure 1A and 1B). The clinical examination revealed caries free teeth, satisfactory oral hygiene and adequate occlusion. After anamneses and clinical examination, patient and clinician decided for a conservative approach treatment using nanofilled composite resin restorations.
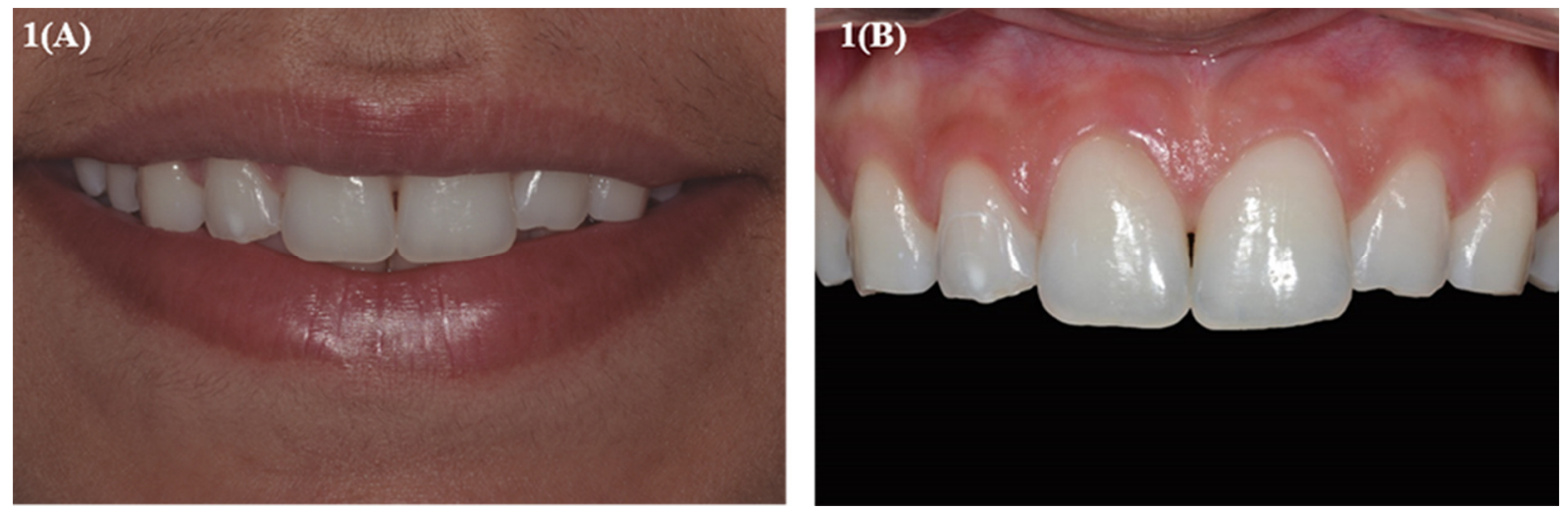

Figure 1. Initial photograph. (A) - Smile view. (B) - Intraoral anterior teeth view

Previously to the restorative treatment, a home bleaching was conducted for 15 days until the teeth reached $\mathrm{B} 1$ shade. The direct restoration through the free-hand technique does not require dental preparation. Initially, a prophylaxis with rubber cup and pumice stone was performed. For control of the oral moisture, a relative isolation with mouth opener, retraction cord (\# 000, Ultradent Products Inc., USA) and sucker was made. The enamel was conditioned by $37 \%$ phosphoric acid (Condac, FGM, Brazil) for 30s, rinse for 30s and dried. An adhesive (Scotchbond Multiporpuse, 3M ESPE, USA) was applied on the tooth structure and light-cured for 20s with a LED unit (RadiiCal, SDI, Australia).

A B1 shade (Filtek Z350 XT, 3M ESPE, USA) nanofilled composite resin for enamel and dentin was carefully introduced using free-hand technique. Composite resin increments were inserted by layering technique: the dentin composite resin was introduced first and the restoration finalized with enamel composite resin to mimic the tooth macrotexture (Figure $2 \mathrm{~A}, 2 \mathrm{~B}$ and 9 A). Each increments was light-cured for 20s. A mylar strip was placed on interproximal to create a tight contact area and to correct the edge form.
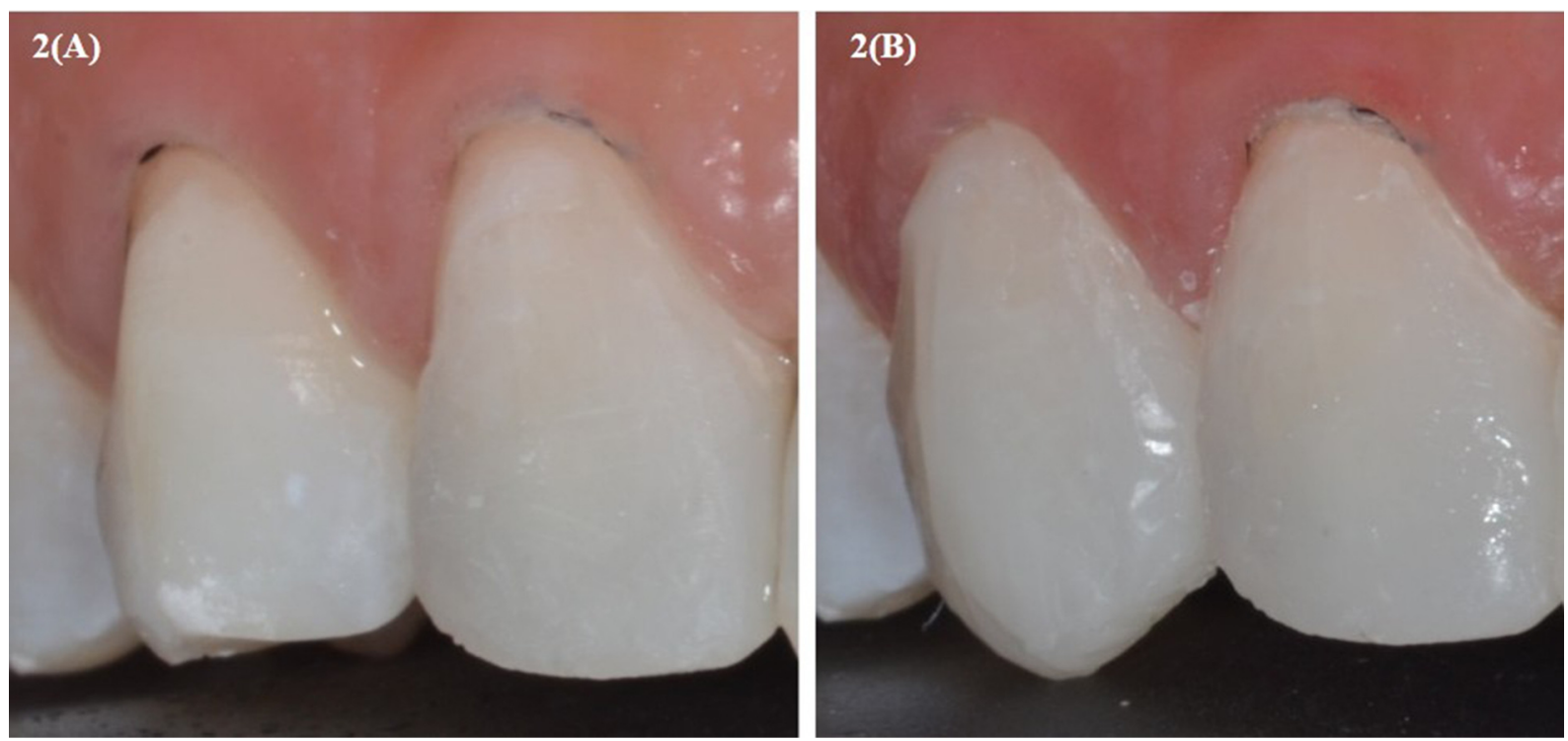

Figure 2. Increments of enamel composite resin in canine and incisor lateral. (A) - Initial. (B) - After insertion of composite resin. 
After the restorations were completed, occlusal and esthetic adjustments were made (Figure 3 ). The finishing and polishing procedures were completed using fine and extra-fine diamond burs (KG Sorensen, Brazil), three coarse silicone cup with different granulations (Jiffy Polishers, Ultradent, USA) goat hair wheel, followed by a disk edge high gloss (DhPro, Brazil) (Figure 4 A, 4 B and $9 \mathrm{~A})$.

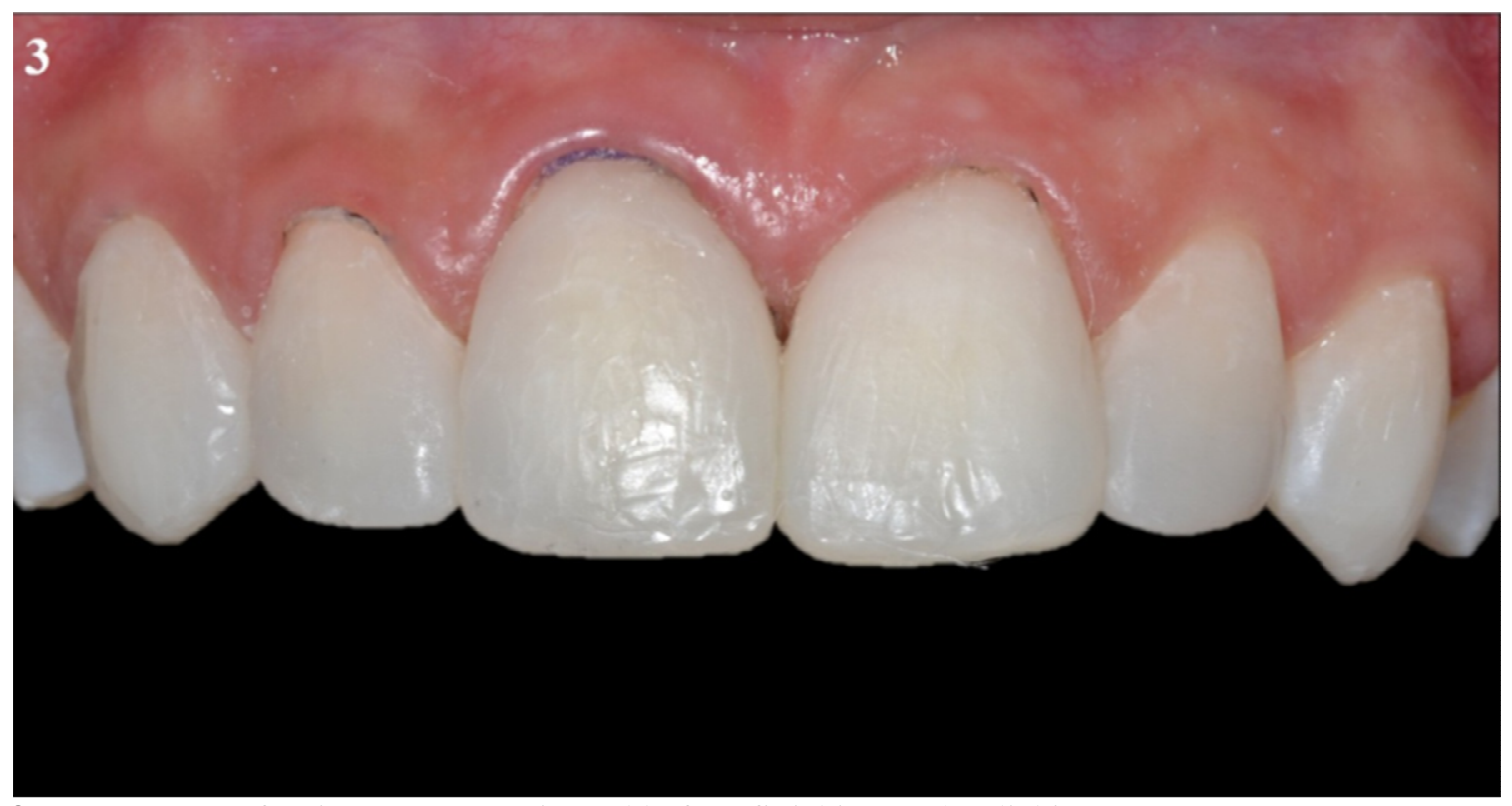

Figure 3. Appearance after increments resin and before finishing and polishing.
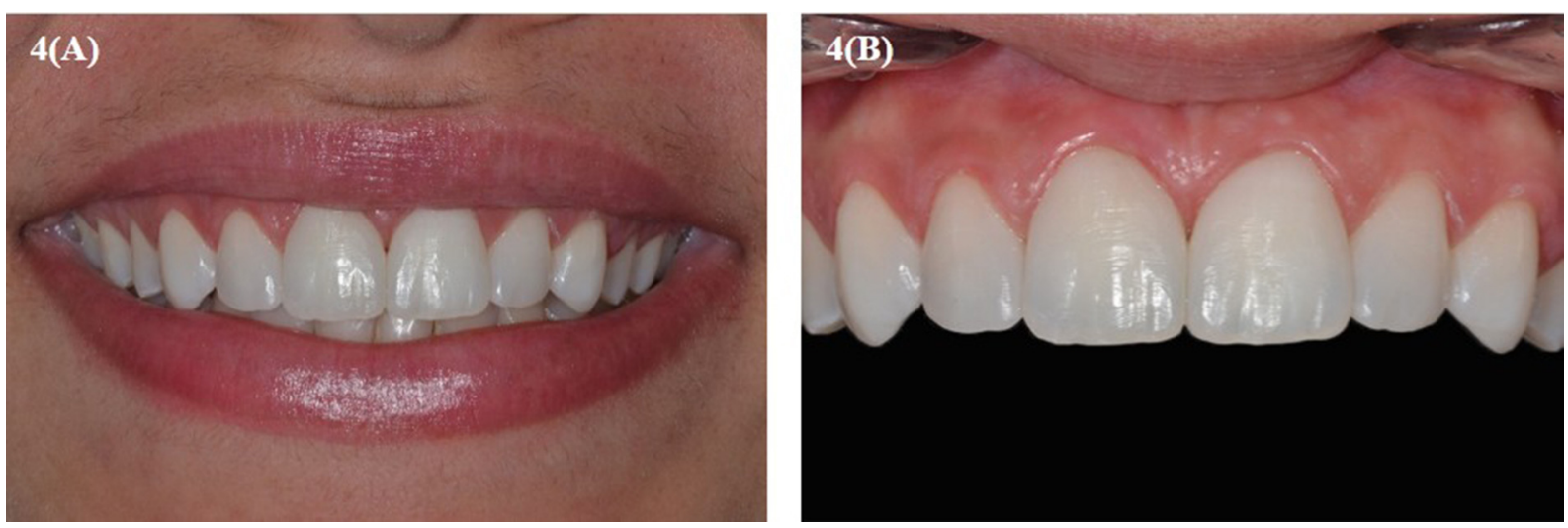

Figure 4. Final appearance of restorations after finishing and polishing. (A)- Smile view. (B)- Intraoral view

Case 2 - Ceramic Laminates Veneers (CLVs):

A 24-year-old patient, man, attended to the School of Dentistry of Federal University of Uberlandia, dissatisfied with his smile, particularly due to the anatomic shape of his maxillary anterior conoid teeth (Figure 5A and 5B). Clinical examination revealed good periodontal health, stable occlusion, normal vertical and horizontal overlap, and canine-protected guidance. Based on the evaluation, was decided for a conservative approach treatment using minimally invasive CLVs. The impressions of the patient's dental arches were performed with addition silicone (Express XT, 3M, USA). For the treatment planning, the wax-up was made to define shape and dental dimensions (Figure 6A). After that, the mock-up was performed filling a silicone matrix with bis-acrylic resin (Systemp, Ivoclar Vivadent, Brazil) (Figure 6B, 6C and 6D). 

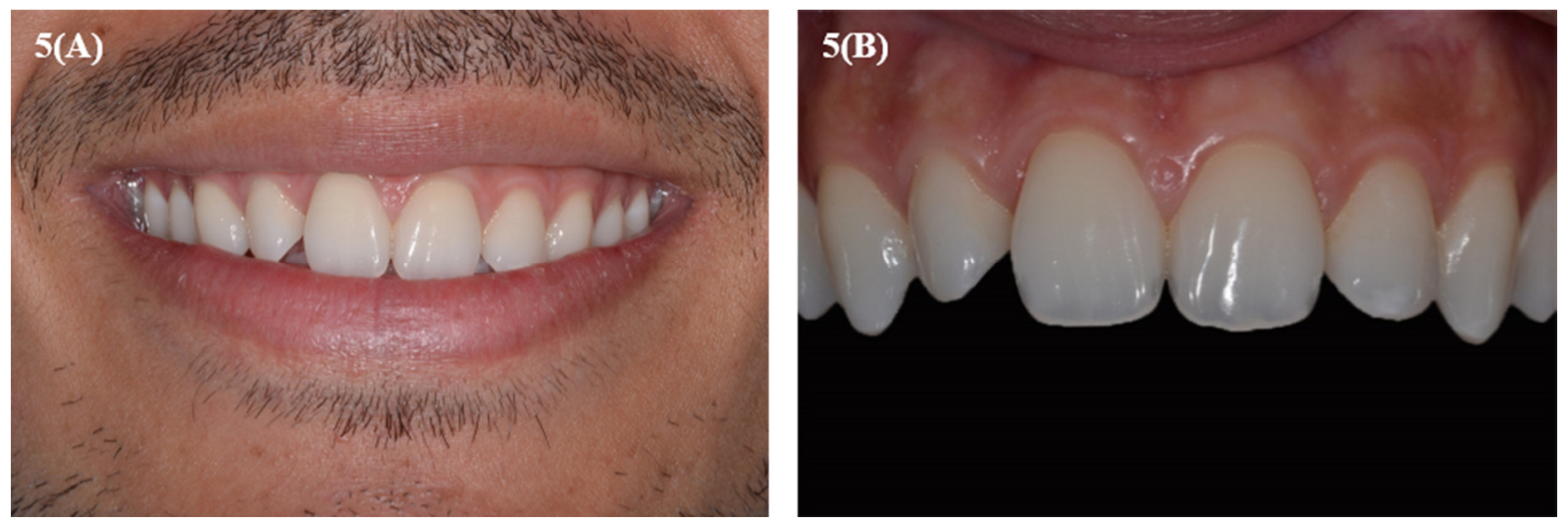

Figure 5. Initial appearance. (A) - Smile view. (B) - Intraoral view.
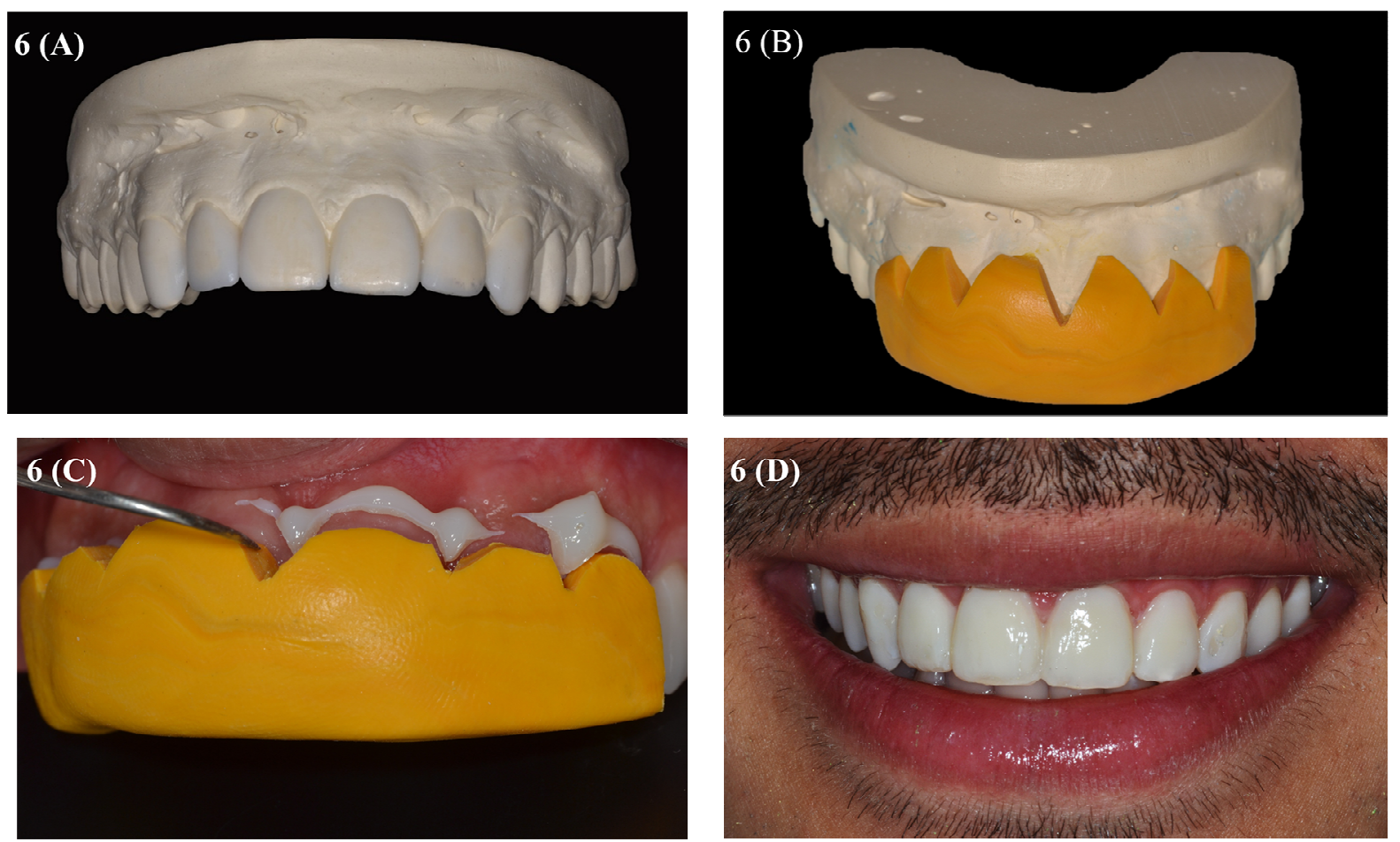

Figure 6. (A) - Wax-up. (B) - Silicon Matrix. (C) - Matrix prove mouth and removing of excess of bis-acrylic resin. (D) - Final Aspect of Mock-up.

An approximately $0.3 \mathrm{~mm}$ minimally invasive prepare was done on maxillary central and lateral incisor using a diamond bur (\#2214 F, KG Sorensen, Brazil) (Figure 7A and 7B). These prepares were performed to ensure the direction of the ceramic laminate veneers insertion and to round off sharp angles promoting higher resistance of restorative materials. Then, the impression was done using addition silicone and retraction cord (\#000, Ultradent Products, Inc., USA). A shade guide Vita Classical guide (Vitapan Classical, Germany) was used to determine tooth shade (B1). CLVs restorations were fabricated with glass-ceramic feldspathic (Vita VM13, Vita, Germany).

The CLVs were tested to ensure the symmetry, shape and proximal contacts. The cement shade was selected and tested using try-in paste
(Variolink Veneer Try-In; Ivoclar Vivadent, Germany). The veneers internal surfaces were etched by $9.5 \%$ hydrofluoric acid for $2 \mathrm{~min}$ (Dentsply, USA) and washed. The $37 \%$ phosphoric acid was applied for $60 \mathrm{~s}$ (Total Etch, Ivoclar Vivadent, Germany). After the rinse, the internal surface was dried with air jets and the veneers were silanized with a silane coupling agent for 60s (Monobond Plus, Ivoclar Vivadent, Alemanha). The teeth surface was conditioned by $37 \%$ phosphoric acid for $30 \mathrm{~s}$, rinsed for $30 \mathrm{~s}$ and moisture control with air jet. After these, the adhesive agent (Scotchbond, 3M ESPE, USA) was applied on the enamel and photo-cured for $20 \mathrm{~s}$. A light-cured -1 value resin cement (Variolink Veneer, Ivoclar Vivadent, Alemanha) was used to cement the veneer on upper right lateral incisor and medium value was 
use to cement all others veneers. The cement excess was removed and all tooth surfaces were lightcured for $60 \mathrm{~s}$ by LED unit. Occlusal contacts were checked and the esthetic and cosmetic adjustments were done after cementation with extra-fine diamond burs (KG Sorensen, Cotia SP, Brazil) (Figure 8A, 8B and 9B).
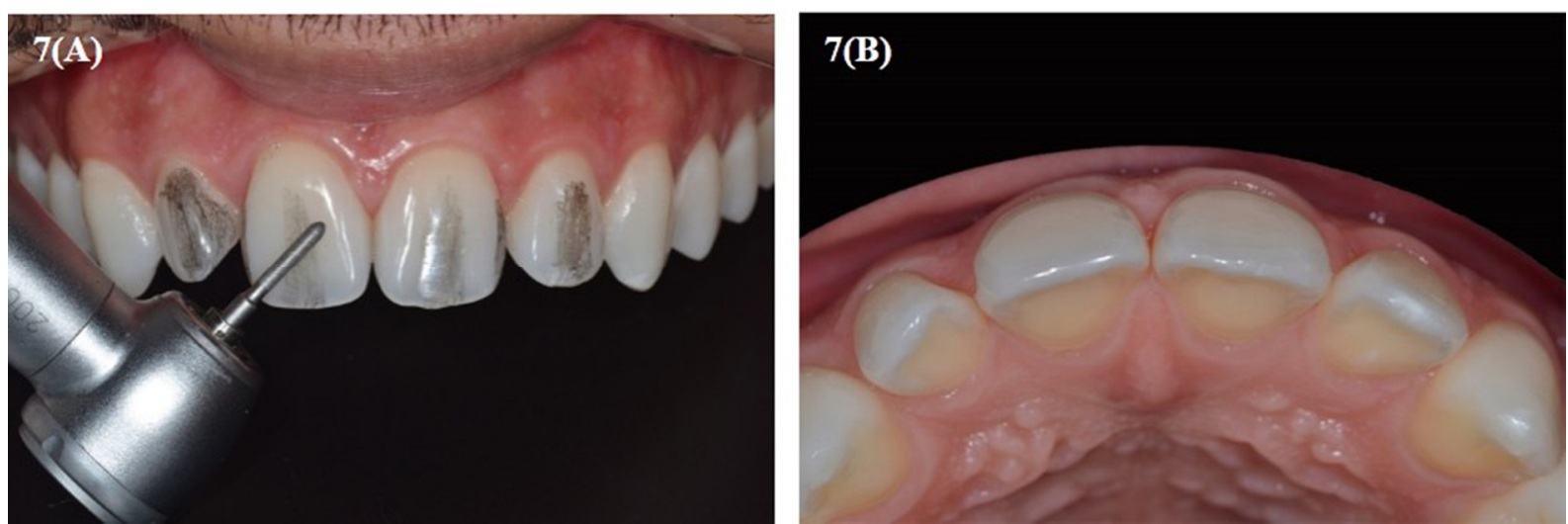

Figure 7. (A) - Minimally invasive prepare with diamond fine burs on the enamel surface. (B)- Occlusal view after preparation.
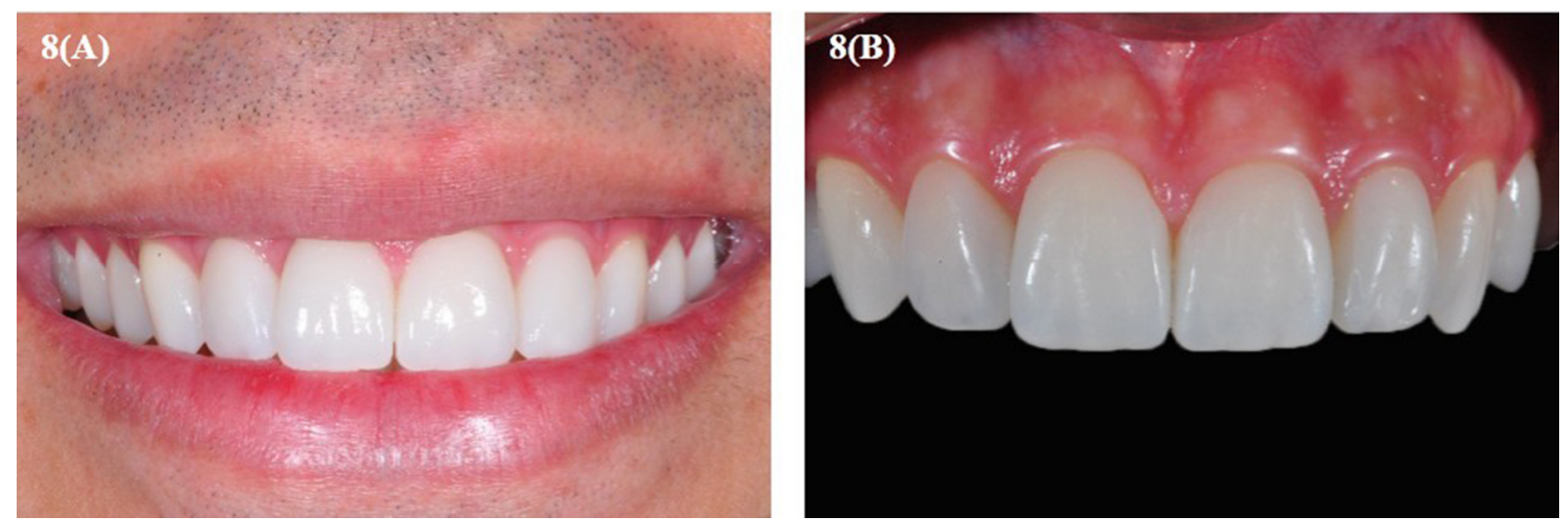

Figure 8. Intraoral appearance after esthetics adjustments made in the CLVs. (A)- Smile view. (B)- Intraoral view.
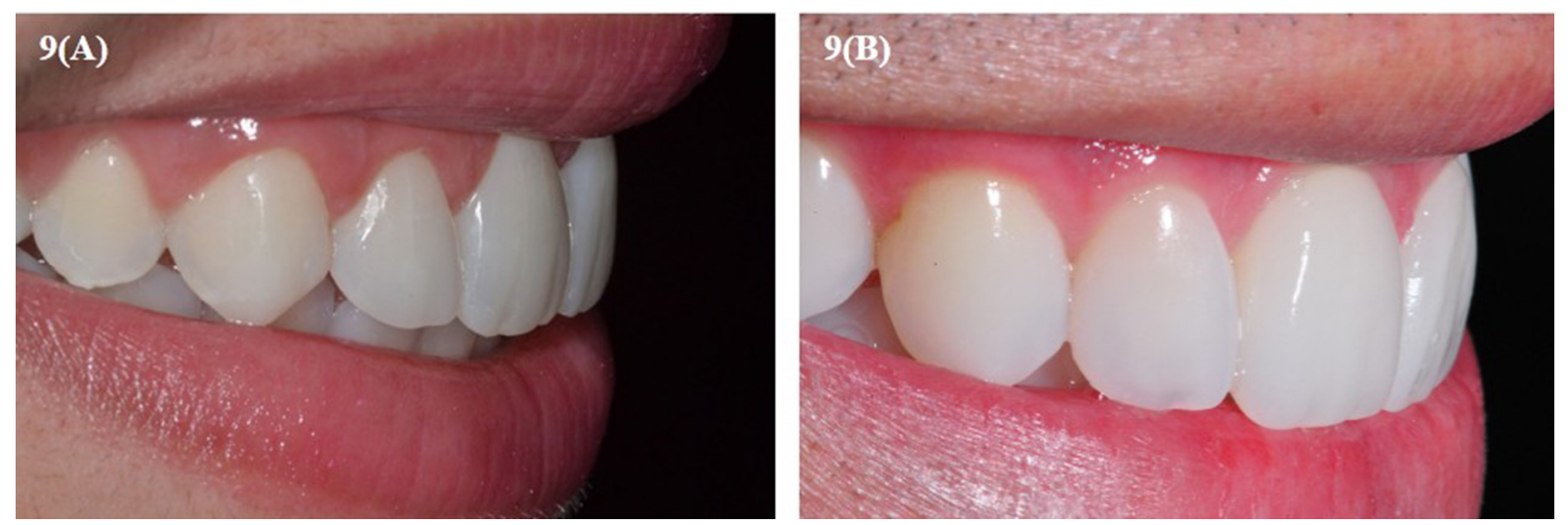

Figure 9. A Postoperative view of right side of the maxillary anterior teeth. (A) - Case 1. (B) - Case 2.

\section{DISCUSSION}

Teeth with harmonic appearance and attractive smiles have positive effects on the patient's self-esteem and psychosocial well-being (DONG et al., 1999). For this reason, esthetic rehabilitation has become increase popular. The direct composite resin restorations and ceramic laminate veneers restorations promote excellent outcomes for esthetic alterations, such as fracturing, teeth discoloration and diastema (ALBANESI et al., 2016; DIETSCHI, 2008; COTERT; DUNDAR; 
OZTURK, 2009; GRESNIGT; KALK; OZCAN, 2012). Nevertheless, both restorative techniques have specific limitations and advantages that must be considered on the treatment planning.

The composite resin evolution resulted in improvement of their mechanical properties, such as fracture and wear resistance, especially with the development of nanofilled resins (JANUS et al., 2010; FRESE et al., 2013). This material promotes a gloss and texture surface satisfactory; that minimize the bacterial plaque accumulation and restoring function and esthetic. In addition, ensure the patient the possibility of oral hygiene and periodontal health (FERRACANE, 2011). The survival rate of anterior resin restorations is predicted to be of $84.6 \%$ after 5 years of clinical service (FRESE et al., 2013), with annual failure rates which varies from 0 to $4.1 \%$ (DEMARCO et al., 2015). Fracturing/chipping, caries, staining, color deterioration and change on the surface roughness are the most frequent complications of this technique (SILVA et al., 2015; GRESNIGT; KALK; OZCAN, 2012; BALDISSERA et al., 2013; FRESE et al., 2013; HEINTZE; ROUSSON; HICKEL, 2015). However, repairing (FERRACANE, 2011) or refurbishing may resolve some of these complications. The functional survival rate of $100 \%$ is attributable to the easiness in repairing such restorations, which enables a patient-oriented and tooth-oriented approach treatment (GRESNIGT; KALK; OZCAN, 2012). Furthermore, the direct restoration do not necessary enamel roughening, whereas the phosphoric acid are enough to improve the bond strength between the enamel to composite resin, and even preserve tooth structure (SENGUN et al., 2008).

The principal advantages of composite resin restorations are low-cost and its reversibility (GRESNIGT; KALK; OZCAN, 2012). Nevertheless, the free-hand technique requires a learn curve to apply composite resin due to it involves extensive training (GRESNIGT; KALK; OZCAN, 2012). The success of this procedure depends on understanding of the intimate structure of sound teeth (MAGNE; HOLZ, 1996) in order to select the suitable color, build up anatomical shape and surface texture (PONTONS-MELO; FURUSE; MONDELLI, 2011).

The feldspathic ceramics is a type of vitreous ceramic system, set to a non-crystalline silica-based glass and potassium feldspar or sodium feldspar. Glass, opacifiers and pigments are added to control the melting, sintering temperature, thermal expansion coefficient and solubility (ANUSAVICE, 1996). This ceramic was a pioneer in the dental market that currently has high resistance to compression and abrasion, when effectively adhered to the dental tissues. Furthermore, this ceramic has optical properties of quality and biological compatibility, thus, creating, color stability and esthetic results satisfactory (MIYASHITA, FONSECA, 2004). The performance of the rehabilitation using feldspathic veneers was evaluated by several clinical trials, which presented a survival rate of $95.6 \%$ after 10 years (BALDISSERA et al., 2013). The most common complications were ceramics fracturing, cracking and chipping, as well as marginal discoloration (ARISTIDIS; DIMITRA, 2002; BEIER; KAPFERER; DUMFAHRT, 2012)

The use of CLVs requires enamel preparation and bonding (MORIMOTO et al., 2016). This technique increase reversibility and improves micromechanical bond in comparison to dentin (SWIFT; PERDIGAO; HEYMANN, 1995). Additionally, its high elasticity modulus allows the enamel to sustain the fragile porcelain as a natural substructure (LAYTON; CLARKE, 2013). The absence more invasive dental prepare, makes temporary restorations unnecessary and simplifies the impression technique. These are also others advantages of this minimally invasive restoration (FARIAS-NETO et al., 2015).

On another hand, not all patients are suitable candidates to CLV procedure (RADZ, 2011). The high cost of the treatment and occlusal instability are primary limitation to be considered. Due to the thin thickness of the CLVs, which increases the risks of irreparable fractures, when occlusal forces act, it is important to be careful with patients that presents parafunction. The estimated CLVs failure risk was almost 8 times higher in patients with bruxism if compared to patients without bruxism episodes (BEIER; KAPFERER; DUMFAHRT, 2012). Moreover, for all restorations considered in general, the estimated risk was almost 3 times higher (BEIER; KAPFERER; DUMFAHRT, 2012). Due to the possibility of repair, composite resins restorations are more favorable in these situations (HICKEL; BRUSHAVER; ILIE, 2013). Furthermore, it is recommended that patients with bruxism use an occlusal splint in order to protect restorations and teeth (BEIER; KAPFERER; DUMFAHRT, 2012).

In order to facilitate the treatment planning of extensive cases, a wax-up and cosmetic mock-up are recommended. The wax-up is a study model that present build- up wax teeth and the mock-up is obtained from silicon matrix filling with bis-acrylic resin (BEIER; KAPFERER; DUMFAHRT, 2012; 
SWIFT; PERDIGAO; HEYMANN, 1995; SOARES et al., 2014) which provided a real threedimensional in situ visualization of the final shape of the proposed treatment. These procedures offering clinical benefits such as treatment preview and better communication between dentist, patient and ceramist (MUTS et al., 2014). This step is indicate for predictability booth of composite resin restorations and mostly ceramic restoration; due to the main functional and esthetic adjustments. The mock-up enable the immediate perspective of the final restoration on the patient's mouth, thus avoiding unnecessary adjustments after ceramic laminate veneers cementation.

In regards, the CLVs try-in paste is recommended in order to evaluate the matching cement shade (TURGUT; BAGIS; AYAZ, 2014). As it depends on the thickness of the veneer and the dental shade, different cements shade can be selected for different teeth on the same patient. The dual composite resin cement and self-curing is not indicated, due to the degradation of residual amines and to the oxidation of residual unreacted carboncarbon double bonds, that result in color instability (TURGUT; BAGIS, 2011). Therefore, it is essential that exclusively light-cured resin cement be used. Due to the thin thickness of CLVs, this technique is contraindicated on severe discolored teeth. These restorations are unable to mask the dark color. In these situations, both direct and indirect restorations requires a more invasive preparation (DOZIC et al., 2010).

\section{CONCLUSION}

The success of minimally invasive restorations is dependent on the case selection, detailed planning and correct selection of dental materials. Direct and indirect treatments were successful in promoting esthetics and fulfilling their functions. Although it is important to know the limitations and advantagesf the two different techniques for long-lasting and highly successful restorations.

RESUMO: Dentes com formato anatômico insatisfatório podem causar desarmonia na estética do sorriso. Os tratamentos para restabelecer a estética do sorriso vêm evoluindo concomitantemente com o desenvolvimento dos materiais dentários. A odontologia estética permite um preparo minimamente invasivo através de resinas compostas e laminados cerâmicos. Estes dois métodos de tratamento apresentam algumas vantagens e desvantagens. O objetivo deste artigo é descrever dois relatos de casos clínicos e comparar alternativas para a reabilitação da estética do sorriso pelos tratamentos minimamente invasivos diretos e indiretos. No primeiro caso, paciente de 24 anos do gênero feminino, estava descontente com o tamanho e com o desgaste incisal dos dentes maxilares anteriores. Após o planejamento funcional e estético foi indicado restauração direta com uma resina nanopartículada pela técnica da mão livre. No segundo caso, paciente de 24 anos do gênero masculino relatou insatisfação com a forma dos incisivos centrais superiores. No exame clínico foi observado incisivos conoídes. Baseado no exame clínico foi planejado um tratamento conservador com laminados cerâmicos nos incisivos centrais e laterais, e fragmentos cerâmicos nos caninos. Pode-se concluir que os tratamentos conservadores utilizando resina composta e laminados cerâmicos, mesmo com suas limitações, promove uma estética satisfatória e resultados funcionais preservando a estrutura dental.

PALAVRAS-CHAVE: Preparo dental. Diastemas. Dentística cosmética.

\section{REFERENCES}

ALBANESI, R. B.; PIGOZZO, M. N.; SESMA, N.; LAGANA, D. C.; MORIMOTO, S. Incisal coverage or not in ceramic laminate veneers: A systematic review and meta-analysis. J Dent, Bristol, v. 52, n., p. 1-7, 2016.

ANUSAVICE, KJ. Phillip’s science of dental materials. 10 ed. Philadelphia: Company, 1996.

ARISTIDIS, G. A.; DIMITRA, B. Five-year clinical performance of porcelain laminate veneers. Quintessence Int, Rochester, v. 33, n. 3, p. 185-189, 2002.

BALDISSERA, R. A.; CORREA, M. B.; SCHUCH, H. S.; COLLARES, K.; NASCIMENTO, G. G.; JARDIM, P. S.; MORAES, R. R.; OPDAM, N. J.; DEMARCO, F. F. Are there universal restorative composites for anterior and posterior teeth? J Dent, Bristol, v. 41, n. 11, p. 1027-1035, 2013.

https://doi.org/10.1016/j.jdent.2013.08.016 
BEIER, U. S.; KAPFERER, I.; DUMFAHRT, H. Clinical long-term evaluation and failure characteristics of 1,335 all-ceramic restorations. Int J Prosthodont, Chicago, v. 25, n. 1, p. 70-78, 2012.

COTERT, H. S.; DUNDAR, M.; OZTURK, B. The effect of various preparation designs on the survival of porcelain laminate veneers. J Adhes Dent, New Malden, v. 11, n. 5, p. 405-411, 2009.

DEMARCO, F. F.; COLLARES, K.; COELHO-DE-SOUZA, F. H.; CORREA, M. B.; CENCI, M. S.;

MORAES, R. R.; OPDAM, N. J. Anterior composite restorations: A systematic review on long-term survival and reasons for failure. Dent Mater, Copenhagen, v. 31, n. 10, p. 1214-1224, 2015.

https://doi.org/10.1016/j.dental.2015.07.005

DIETSCHI, D. Optimising aesthetics and facilitating clinical application of free-hand bonding using the 'natural layering concept'. Br Dent J, Riberão Preto, v. 204, n. 4, p. 181-185, 2008.

https://doi.org/10.1038/bdj.2008.100

DONG, J. K.; JIN, T. H.; CHO, H. W.; OH, S. C. The esthetics of the smile: a review of some recent studies.

Int J Prosthodont, Chicago, v. 12, n. 1, p. 9-19, 1999.

DOZIC, A.; TSAGKARI, M.; KHASHAYAR, G.; ABOUSHELIB, M. Color management of porcelain veneers: influence of dentin and resin cement colors. Quintessence Int, Rochester, v. 41, n. 7, p. 567-573, 2010.

FARIAS-NETO, A.; GOMES, E. M.; SANCHEZ-AYALA, A.; VILANOVA, L. S. Esthetic Rehabilitation of the Smile with No-Prep Porcelain Laminates and Partial Veneers. Case Rep Dent, Cairo, v. 2015, n., p. $452765,2015$.

FERRACANE, J. L. Resin composite--state of the art. Dent Mater, Copenhagen, v. 27, n. 1, p. 29-38, 2011. https://doi.org/10.1016/j.dental.2010.10.020

FRESE, C.; SCHILLER, P.; STAEHLE, H. J.; WOLFF, D. Recontouring teeth and closing diastemas with direct composite buildups: a 5-year follow-up. J Dent, Bristol, v. 41, n. 11, p. 979-985, 2013.

https://doi.org/10.1016/j.jdent.2013.08.009

GRESNIGT, M. M.; KALK, W.; OZCAN, M. Randomized controlled split-mouth clinical trial of direct laminate veneers with two micro-hybrid resin composites. J Dent, Bristol, v. 40, n. 9, p. 766-775, 2012. https://doi.org/10.1016/j.jdent.2012.05.010

HEINTZE, S. D.; ROUSSON, V.; HICKEL, R. Clinical effectiveness of direct anterior restorations--a metaanalysis. Dent Mater, Copenhagen, v. 31, n. 5, p. 481-495, 2015. https://doi.org/10.1016/j.dental.2015.01.015

HICKEL, R.; BRUSHAVER, K.; ILIE, N. Repair of restorations--criteria for decision making and clinical recommendations. Dent Mater, Copenhagen, v. 29, n. 1, p. 28-50, 2013.

https://doi.org/10.1016/j.dental.2012.07.006

JANUS, J.; FAUXPOINT, G.; ARNTZ, Y.; PELLETIER, H.; ETIENNE, O. Surface roughness and morphology of three nanocomposites after two different polishing treatments by a multitechnique approach. Dent Mater, Copenhagen, v. 26, n. 5, p. 416-425, 2010. https://doi.org/10.1016/j.dental.2009.09.014

KORKUT, B.; YANIKOGLU, F.; TAGTEKIN, D. Direct Midline Diastema Closure with Composite Layering Technique: A One-Year Follow-Up. Case Rep Dent, Cairo, v. 2016, n., p. 6810984, 2016.

LAYTON, D. M.; CLARKE, M. A systematic review and meta-analysis of the survival of non-feldspathic porcelain veneers over 5 and 10 years. Int J Prosthodont, Lombard, v. 26, n. 2, p. 111-124, 2013. https://doi.org/10.11607/ijp.3202 
MAGNE, P.; HOLZ, J. Stratification of composite restorations: systematic and durable replication of natural aesthetics. Pract Periodontics Aesthet Dent, New York, v. 8, n. 1, p. 61-68; quiz 70, 1996.

MIYASHITA E, FONSECA AS. Odontologia estética: o estado da arte. São Paulo: Artes Médicas; São Paulo, 2004.

MORIMOTO, S.; ALBANESI, R. B.; SESMA, N.; AGRA, C. M.; BRAGA, M. M. Main Clinical Outcomes of Feldspathic Porcelain and Glass-Ceramic Laminate Veneers: A Systematic Review and Meta-Analysis of Survival and Complication Rates. Int J Prosthodont, Lombard, v. 29, n. 1, p. 38-49, 2016. https://doi.org/10.11607/ijp4315

MUTS, E. J.; VAN PELT, H.; EDELHOFF, D.; KREJCI, I.; CUNE, M. Tooth wear: a systematic review of treatment options. J Prosthet Dent, St. Louis, v. 112, n. 4, p. 752-759, 2014.

https://doi.org/10.1016/j.prosdent.2014.01.018

OQUENDO, A.; BREA, L.; DAVID, S. Diastema: correction of excessive spaces in the esthetic zone. Dent Clin North Am, Philadelphia, v. 55, n. 2, p. 265-281, viii, 2011.

PONTONS-MELO, J. C.; FURUSE, A. Y.; MONDELLI, J. A direct composite resin stratification technique for restoration of the smile. Quintessence Int, Rochester, v. 42, n. 3, p. 205-211, 2011.

RADZ, G. M. Minimum thickness anterior porcelain restorations. Dent Clin North Am, Philadelphia, v. 55, n. 2, p. 353-370, ix, 2011.

SENGUN, A.; ORUCOGLU, H.; IPEKDAL, I., OZER, F. Adhesion of two bonding systems to air-abraded or bur-abraded human enamel surfaces. Eur J Dent, Ankara, v. 2, n. 3, p. 167-75, 2008.

SILVA, M. A.; VITTI, R. P.; SINHORETI, M. A.; CONSANI, R. L.; JUNIOR, J. G.; TONHOLO, J. Evaluation of the Surface Roughness and Microleakage of Dental Composites Exposed to Different Beverages. J Contemp Dent Pract, New Delhi, v. 16, n. 10, p. 800-804, 2015.

SOARES, P. V.; SPINI, P. H.; CARVALHO, V. F.; SOUZA, P. G.; GONZAGA, R. C.; TOLENTINO, A. B.; MACHADO, A. C. Esthetic rehabilitation with laminated ceramic veneers reinforced by lithium disilicate. Quintessence Int, Rochester, v. 45, n. 2, p. 129-133, 2014.

SWIFT, E. J., JR.; PERDIGAO, J.; HEYMANN, H. O. Bonding to enamel and dentin: a brief history and state of the art, 1995. Quintessence Int, Rochester, v. 26, n. 2, p. 95-110, 1995.

TURGUT, S.; BAGIS, B. Colour stability of laminate veneers: an in vitro study. J Dent, Bristol, v. 39 Suppl 3, n., p. e57-64, 201

TURGUT, S.; BAGIS, B.; AYAZ, E. A. Achieving the desired colour in discoloured teeth, using leucite-based CAD-CAM laminate systems. J Dent, Bristol, v. 42, n. 1, p. 68-74, 2014.

https://doi.org/10.1016/j.jdent.2013.10.018 